\title{
Factors Affecting Behavioural Intentions in the Use of Mobile Learning in Higher Education
}

\author{
Nighat Parveen \\ $\mathrm{Ph}$. D. Scholar \\ Department of Education, NUML \\ nighatwadanafridi@gmail.com \\ Dr Shazia Zamir \\ Assistant Professor \\ Department of Education, NUML
}

\begin{abstract}
The technological revolution in the recent era is adding up means of learning. The launch of $3 \mathrm{G} / 4 \mathrm{G}$ technologies supplementing with the latest applications and software have made mobile devices an effective medium for learning. The portable devices are facilitating the newest trends of learning such as e-learning and online learning. This study aimed to explore factors affecting students' behavioural intentions regarding the use mobile learning and to investigate the moderating role of age, gender and programs of studies in the use of mobile learning at higher education level. Data were collected from 45 students through a questionnaire. Statistical techniques like frequencies, mean, correlation coefficient, t-test and one-way ANOVA were used to analyze data. It was concluded that all respondents possessed behavioural intentions to learn through mobile devices. There was no significant difference between the behavioural intentions of male and female respondents for using mobile learning. No significant difference was observed in behavioural intensions of respondents from different age groups and respondents enrolled in different programs to use mobile learning. It is recommended that management of higher education may design and implement the use of mobile devices in learning at higher education.
\end{abstract}

Keywords: Mobile learning, behavioural intentions, e-learning, online learning, higher education.

\section{Introduction}

The lifestyle of modern people is considerably changing with the evolution of handheld portable devices and wireless technologies. The world is now experiencing electronic modes and means of transmission of knowledge. Teaching and learning process is not confined to the boundaries of traditional schools. Modern gadgets have made it easy to follow one's interests and intentions. The expanded canvas of available interests is shrinking time for all activities to be carried out. To make meaningful and productive use of time by youth, it has become significant to direct students' interests towards learning through modern gadgets. It seems as the tradition of a devoted lifetime for institutional learning will get obsolete in the coming future. New modes of online learning are introduced, where students learn at their own pace without physically attending educational institutions at a specific age. This modernization is introducing effective alternatives 
to traditions. The latest terms such as e-learning and online-learning are becoming acceptable and meaningful. Banks (2008) has identified that youth today is getting gradually comfortable with the new digital lifestyles which are powered by the latest technologies such as mobile phones. These latest devices are supplemented with portable entertainment devices like iPods, Xbox, Gameboy, digital cameras, video and audio players. Social circles are built, maintained and lost online in a virtual world. Social networking such as Facebook, Twitter, WhatsApp, Skype etc. are consuming most of the youth's time on mobile devices. Banks (2008) is of the view that this technology is not universally accessible to all. His views invite certain questions that researchers need to explore, such as, what does mobile technology bring to learning?

The mobile devices have enriched the concept of e-learning and online learning since the latest mobile devices are now equipped with features to support a wide range of e-learning and online learning approaches. With the introduction of third and fourth generation (3G and $4 \mathrm{G})$ mobile technologies, the mobile devices now include features of internet connectivity, web browsing, e-mail, GPS functionality, internal storage, wireless broadband connectivity, e-book features, infrared and BlueTooth transmissions, motion sensors, high processing speed, onboard memory and text documents sharing, audio and video recording, podcasting, notes taking, calendar, planners and much more (Prensky, 2001). The unexplored potential of digital devices is now ready to introduce the world with the latest trend of mobile learning as a pedagogical activity in higher educational institutions.

The higher level of education is usually partaken by students who are cognitively independent and mature. They make decisions for their academic progress and have the freedom to choose means of information. The mobile phone is one of the most favorite gadgets of today's youth. There are 139.8 million cellular mobile subscribers in Pakistan. The total number of mobile broadband subscribers is 42.1. There are 55.1 million subscribers with broadband-enabled handsets/smart-phones. Low cost of mobile devices and better functionalities has helped an increase in this number (Annual Report, 2017).

Mobile devices, which are used irrespective of time and place, have become an unavoidable part of human life. The technological changes have also altered the educational environment at campuses. The universities allocate heavy budgets for faster communications and information sharing. Distance education, online learning, electronic learning and mobile learning have been 
introduced to the public. But the readiness of users to accept new technology is of fundamental importance. It is needed to explore the potential and challenges associated with these new modes of learning. Behavioural intentions of learners, teachers and parents are one among such challenges. Whether a student adopts or rejects the new technology? is an important and complex case. If students remain reluctant to use technology, it may lead to structural devastation and may prove to be a meager practice for institutions. Therefore, an investigation is required to assess the behavioural intentions of the students to use mobile devices for the process of education. As defined by Ajzen and Fishbein (1980) behavioural intention is the probability of respondents to perform or do not perform a particular behavior. It involves the conscious plan of a person to act or does not act according to a specific behavior. It makes behavioural intention different from the term 'intention' used in everyday language (Warshaw \& Davis, 1985).

In Pakistan, the opportunities and benefits offered by mobile learning are not investigated sufficiently. Little research has investigated the factors affecting university students behavioural intentions to use mobile learning. The present study was designed to investigate the behavioural intentions in the use of mobile learning at higher education level. The focus of the study was to investigate the following objectives.

\subsection{Objectives of the Study}

1. To analyze the factors affecting students behavioural intentions to use mobile learning at higher education level.

2. To find out the gender difference regarding students' behavioural intentions to use mobile learning at higher education level.

3. To investigate role of age regarding behavioural intentions to use mobile learning at higher education level.

4. To investigate role of program of studies regarding behavioural intentions to use mobile learning at higher education level.

\section{Literature Review}

El-Husseinand Cronje (2010) have defined mobile learning in terms of mobility. They are of the view that any kind of learning that takes place in a learning environment which takes account

of the mobility of technology, learners and learning is termed as mobile learning. Attewell and 
Savill-Smith (2005) explained that mobile learning is the learning process that takes place using wireless devices which can be pocketed and operated anywhere provided the unbroken transmission signals. The most popular feature of the latest smart cellular devices is that these are wireless and portable furthermore, innovative features are constantly being introduced by manufacturers. Therefore, visionary educationists are considering the implications of these devices in modern teaching and learning setups.

Mcconatha, Praul and Lynch (2008) recommended that for quantitative and qualitative growth of mobile learning, instructors are required to experiment with mobile learning. They invited the readers to imagine a classroom where teachers ask a question and students may use their devices to access the information on their own without waiting for the lecture to be delivered. The availability of material and information in this regard has increased the possibility of mobile learning.

Various studies were designed to explore the advantages and disadvantages of mobile learning J. Jo, Moon, Jones and Cranitch (2002) have mentioned that mobile devices have some unique features making them efficient for sharing and exchanging of learning content. These features include portability and mobility, flexibility, convenience, remote accessibility, ease of use and utility. Similarly, Ting (2005) has identified various advantages of mobile learning such as flexibility, accessibility and opportunity for personalized learning. These features engage learners in ongoing learning activities and boost their efficiency and effectiveness. These mobile devices have helped youth with their enhanced sense of individuality and community. Ooms, Linsey and Webb(2008) believe that the enhanced interaction between teacher and student results in effective feedback which helps teachers to modify their teaching. Barker, Krulland Mallinson (2005) concluded that mobile devices may prove to be good assessment tools in the near future. These can give freedom to shy students to express their views well, they have provided a model suggesting mobile learning to fit seamlessly in the prevailing educational settings. This will help the learner with web-based assessment, content delivery and internet access for constant communication and collaboration. In Pakistan, mobile learning can help to mainstream the students of distant and backward areas through e-learning and online learning programs.

Meisenberger and Nischelwitzer (2004) stated some limitations of mobile learning such as limited internal memory and processing power, low-resolution display, variety of screen sizes, 
different input possibilities and various operating systems. These limitations are somehow resolved by the introduction of smart-phones and android technology.

The mobile learning has a focus on learning from learner's point of view. This shift of focus is based not only on technology but also on the ambient and pervasive communications. The major factor that must play its role in mobile learning is the learner himself. Therefore, his readiness and potential for acceptance of mobile technology are necessary. Numerous theories have been established to explain the users' acceptance of any new technology. Technology Acceptance Model (TAM) is one of the earliest models used to explain the user's intentions to adopt a new technology especially in the field of Information Technology (Davis, 1989).

A comparatively latest model is the Unified Theory of Acceptance and Use of Technology (UTAUT) model presented by Venkatesh, Morris, Davis, and Davis (2003). It combines and compares various factors from eight different models and theories. It helps unite systems' and users' characteristics which predict the acceptance of new technology. This model consists of four constructs that are Performance Expectancy, Effort Expectancy, Social Influence and Facilitating Conditions.

Hassan, et al. (2015) conducted a study using UTAUT model to analyze the relationship between behavioural intentions and Performance Expectancy Effort Expectancy Social Influence, Facilitating Condition, Perceived Playfulness Self-management of Learning and Attitude towards the use of technology with gender and age as the moderating factors. They have added three more constructs which are as follows:

Perceived Playfulness: the degree to which a person perceives that his attention is focused on mlearning, is curious during the interaction, and observes the interaction entertaining.

Self-management of Learning: the extent of how much a person notices that he can sustain selfdiscipline and can get involved in self-directed learning.

Attitude towards the use of technology: the general aptitude of an individual towards the use of technology.

Hassan, et al. (2015) discovered that $76.4 \%$ of behavioural intentions to accept mobile learning were explained through this model. Majority of the factors were positively associated with 
the behavioural intentions to adopt mobile learning. It was found that Facilitating conditions and Self-management of learning were negatively related to behavioural intention.

Sundari (2015) in a study found a significant relationship between the learning skills learnt through mobile devices and gender. He concluded that mobile learning is more common in males as compared to females. He also studied the influence of family income, education and family size. The respondents agreed that mobile devices assist them in learning. They can exchange information and can contacteasily their fellows and teachers. The study found that mobile devices have improved their academic performance and quality of education.

There is a greater undiscovered potential for mobile learning in Pakistan. In the current scenario of COVID-19 pandemic and lockdown situations, teachers and students are trying hard to make effective use of mobile technology to fulfill the educational requirements. However, the lack of relevant research work in previous years to handle the current situation is evident. The present study was designed to investigate factors affecting behavioural intentions to use mobile learning in higher education. The important factors affecting behavioural intentions in the use of mobile learning investigated were performance expectancy, effort expectancy, social influence, facilitating conditions, attitudes towards the use of technology usage intentions and anxiety.

\subsection{Theoretical Framework}

The research study was based on the UTAUT model of Venkatesh (2003) and related previous studies. The UTAUT model originally had four major constructs which helped in the investigation of acceptance of new technologies in various fields. To investigate behavioural intentions in using mobile learning three more determinant factors were added including usage intention, attitude towards the use of technology and anxiety. The moderating effects of gender, age and group of studies were also investigated. 


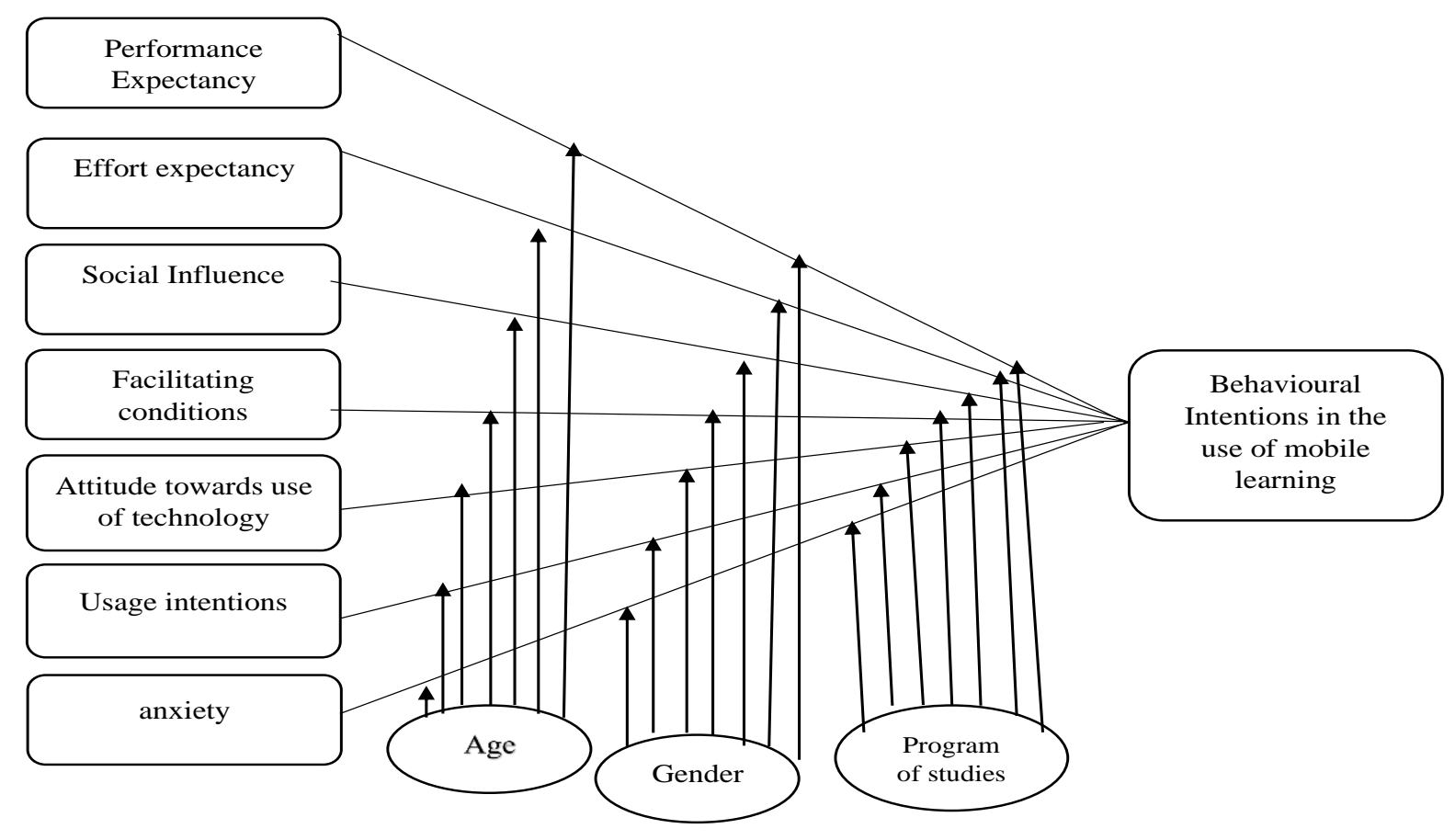

Figure 1 Theoretical Framework for the Study

\section{Methodology}

To achieve the objectives of the study and make generalization effectively, a quantitative approach was adopted for the investigation. A survey-based questionnaire was used to collect data, as the survey is a flexible and affordable method used to describe characteristics of the population in descriptive research for effective generalization of results. The research instrument used for this study consisted of 28 items on seven factors of behavioural intentions for using mobile learning at higher education level. The Cronbach alpha value of .858 showed acceptable reliability of the research instrument. Responses were recorded on the five-point Likert scale. The research instrument contained two parts. The first part comprised items for demographic information and for collection of information regarding the availability and use of mobile devices. Whereas, the second part consisted of statements related to behavioural intentions for the use of mobile devices in the learning process. The behavioural intentions were grouped into seven variables which included performance expectancy, effort expectancy, social influence, facilitating conditions, attitudes towards the use of technology, usage intention and anxiety.

These constructs are operationally defined as follows. 
Behavioural Intention: an individual's opinion that he or she will behave in a certain manner.

Performance Expectancy: it is the extent to which someone believes that using mobile learning will help him/her to achieve his objectives.

Social Influence: the extent to which an individual is influenced by opinions of others in the adoption of mobile learning.

Facilitating Conditions: the extent to which one believes that a structural and methodological system exists to support usage of mobile learning.

Attitude towards the use of technology: the general attitude of an individual towards the use of mobile learning.

Usage Intentions: the extent to which the individual intends to use mobile devices for learning. Anxiety: the extent of perceived fear in using mobile learning.

The population of the study consisted of students studying in the public-sector university. 45 university students ( 9 males and 45 females) from different programs of studies of social sciences department were selected through random sampling technique. Data were analyzed with the help of the Statistical Package of Social Sciences (SPSS). Statistical procedures of frequencies, mean, t-test, ANOVA and correlation coefficient were applied to data.

\section{Data Analysis}

Table1 Correlation Matrix of Factors Affecting Behavioural Intentions to Use Mobile Learning $(N=45)$ 
International Journal of Distance Education and E- Learning (IJDEEL) Volume VI- Issue I (December 2020)

\begin{tabular}{|c|c|c|c|c|c|c|c|}
\hline $\begin{array}{l}\text { Factors Affecting } \\
\text { Behavioural } \\
\text { Intentions to Use } \\
\text { Mobile Learning }\end{array}$ & $\begin{array}{l}\text { Performance } \\
\text { expectancy }\end{array}$ & $\begin{array}{l}\text { Effort } \\
\text { Expectancy }\end{array}$ & $\begin{array}{l}\text { Social } \\
\text { Influence }\end{array}$ & $\begin{array}{l}\text { Facilitating } \\
\text { Conditions }\end{array}$ & $\begin{array}{l}\text { Attitudes } \\
\text { towards Use o } \\
\text { Technology }\end{array}$ & $\begin{array}{l}\text { Usage } \\
\text { f Intention }\end{array}$ & Anxiety \\
\hline $\begin{array}{l}\text { Performance } \\
\text { Expectancy }\end{array}$ & 1 & & & & & & \\
\hline Effort Expectancy & $.687^{* *}$ & 1 & & & & & \\
\hline Social Influence & $.589^{* *}$ & $.421^{* *}$ & 1 & & & & \\
\hline $\begin{array}{l}\text { Facilitating } \\
\text { Conditions }\end{array}$ & $.503^{* *}$ & $.594^{* *}$ & $.582^{* *}$ & 1 & & & \\
\hline $\begin{array}{l}\text { Attitudes towards Use } \\
\text { of Technology }\end{array}$ & ${ }_{* *}^{.6} .637$ & $.706^{* *}$ & $.400^{* *}$ & $.594^{* *}$ & 1 & & \\
\hline Usage Intention & .635 & $.680^{* * *}$ & $.420^{* *}$ & $.572^{* * *}$ & $.863^{* *}$ & 1 & \\
\hline Anxiety & .196 & -.076 & .281 & .230 & .159 & .217 & 1 \\
\hline
\end{tabular}

** Correlation is significant at the 0.01 level (2-tailed).

The Table 1 shows correlation of factors affecting behavioural intentions of respondents to use mobile learning. It is observed that all the factors are positively and significantly correlated $(p<$ .01) except anxiety which is positively but not significantly correlated.

Table2. Means of Factors Affecting Behavioural Intentions to Use Mobile Learning $(N=45)$

\begin{tabular}{lll}
\hline Factors Affecting Behavioural & Means & Remarks \\
Intentions to Use Mobile Learning & &
\end{tabular}

Performance Expectancy

Effort Expectancy $\quad 4.07$

Often

Social Influence

Often

Facilitating Conditions

Often

Attitudes towards Use of

Technology

Often 
Usage Intention

Anxiety
3.93

3.09
Often

Sometimes

Table 2 shows the mean value of respondents' scores on the variables of behavioural intentions. It is indicated that students often agreed on all factors affecting behavioural intentions except the anxiety factor in the use of mobile learning. They sometimes agreed on the anxiety factor.

Table3 Difference between Male and Female Students on Factors Affecting Behavioural Intentions to Use Mobile Learning (N=45)

\begin{tabular}{|c|c|c|c|c|c|c|c|}
\hline \multirow{3}{*}{$\begin{array}{l}\text { Factors Affecting } \\
\text { Behavioural Intentions } \\
\text { to Use Mobile Learning }\end{array}$} & \multirow{2}{*}{\multicolumn{2}{|c|}{$\begin{array}{l}\text { Males } \\
\mathrm{N}=9\end{array}$}} & \multirow{2}{*}{\multicolumn{2}{|c|}{$\begin{array}{c}\text { Females } \\
\mathrm{N}=36\end{array}$}} & \multirow[t]{3}{*}{$\mathrm{t}$} & \multirow[t]{3}{*}{ Sig } & \multirow[t]{3}{*}{ df } \\
\hline & & & & & & & \\
\hline & $\mathrm{M}$ & SD & M & SD & & & \\
\hline Performance & 16.33 & 3.742 & 14.25 & 4.410 & 1.302 & .200 & 43 \\
\hline \multicolumn{8}{|l|}{ Expectancy } \\
\hline Effort Expectancy & 16.89 & 2.934 & 16.11 & 3.934 & .554 & .583 & 43 \\
\hline Social Influence & 14.11 & 4.540 & 13.78 & 3.750 & .229 & .820 & 43 \\
\hline Facilitating Conditions & 20.89 & 4.106 & 19.19 & 3.495 & 1.257 & .216 & 43 \\
\hline Attitudes towards Use & 16.78 & 3.456 & 15.44 & 3.938 & .928 & .358 & 43 \\
\hline \multicolumn{8}{|l|}{ of Technology } \\
\hline Usage Intention & 11.89 & 2.848 & 11.75 & 3.384 & .113 & .910 & 43 \\
\hline Anxiety & 11.89 & 5.622 & 12.47 & 3.509 & .392 & .697 & 43 \\
\hline
\end{tabular}

Table 3 indicates t-value on factors affecting behavioural intentions to use mobile learning. The t-value for performance expectancy, effort expectancy, social influence, facilitating 
conditions, attitudes towards the use of technology, usage intention and anxiety is $1.302, .554$, $.229,1.257, .928, .113$ and .392 respectively. It is concluded that there is no significant difference in behavioural intentions of male and female respondents for using mobile learning.

Table4. ANOVA for Use of Mobile Learning on Factors Affecting Behavioural Intentions among Different Age Groups at Higher Level Education

$(N=45)$

\begin{tabular}{|c|c|c|c|c|c|c|}
\hline \multicolumn{2}{|c|}{$\begin{array}{l}\text { Factors Affecting Behavioural } \\
\text { Intentions to Use Mobile Learning }\end{array}$} & \multirow{2}{*}{$\begin{array}{r}\begin{array}{r}\text { Sum of } \\
\text { Squares }\end{array} \\
38.878\end{array}$} & \multicolumn{2}{|c|}{ df Mean Square } & \multirow{2}{*}{$\begin{array}{r}\mathrm{F} \\
1.259\end{array}$} & \multirow{2}{*}{$\begin{array}{l}\text { Sig. } \\
.289\end{array}$} \\
\hline Performance & Between Groups & & 12 & 3.240 & & \\
\hline \multirow[t]{2}{*}{ Expectancy } & Within Groups & 82.367 & 32 & 2.574 & & \\
\hline & Total & 121.244 & 44 & & & \\
\hline \multirow[t]{3}{*}{ Effort Expectancy } & Between Groups & 36.217 & 12 & 3.018 & 1.136 & .368 \\
\hline & Within Groups & 85.028 & 32 & 2.657 & & \\
\hline & Total & 121.244 & 44 & & & \\
\hline \multirow[t]{3}{*}{ Social Influence } & Between Groups & 27.197 & 14 & 1.943 & .620 & .828 \\
\hline & Within Groups & 94.048 & 30 & 3.135 & & \\
\hline & Total & 121.244 & 44 & & & \\
\hline \multirow[t]{3}{*}{ Facilitating Conditions } & Between Groups & 30.161 & 13 & 2.320 & .790 & .665 \\
\hline & Within Groups & 91.083 & 31 & 2.938 & & \\
\hline & Total & 121.244 & 44 & & & \\
\hline \multirow{3}{*}{$\begin{array}{l}\text { Attitudes towards Use } \\
\text { of Technology }\end{array}$} & Between Groups & 20.286 & 12 & 1.691 & .536 & .875 \\
\hline & Within Groups & 100.958 & 32 & 3.155 & & \\
\hline & Total & 121.244 & 44 & & & \\
\hline \multirow[t]{3}{*}{ Usage Intention } & Between Groups & 13.649 & 8 & 1.706 & .571 & .795 \\
\hline & Within Groups & 107.596 & 36 & 2.989 & & \\
\hline & Total & 121.244 & 44 & & & \\
\hline \multirow[t]{3}{*}{ Anxiety } & Between Groups & 51.183 & 15 & 3.412 & 1.412 & .206 \\
\hline & Within Groups & 70.062 & 29 & 2.416 & & \\
\hline & Total & 121.244 & 44 & & & \\
\hline
\end{tabular}

Table4 indicates that $\mathrm{F}$ value is not significant at 0.05 level of significance. Therefore, it is concluded that there is no significant difference in behavioural intentions of different age groups for using mobile learning on all its variables. 
International Journal of Distance Education and E- Learning (IJDEEL) Volume VI- Issue I (December 2020)

Table5. ANOVA for Use of Mobile Learning on Factors Affecting Behavioural Intentions among Different Programs of Studies at Higher Level Education $(N=45)$

\begin{tabular}{|c|c|c|c|c|c|c|}
\hline $\begin{array}{l}\text { Factors Affectin } \\
\text { Intentions to Use M }\end{array}$ & $\begin{array}{ll}\text { Ig } & \text { Behavioural } \\
\text { lobile Learning }\end{array}$ & $\begin{array}{r}\text { Sum of } \\
\text { Squares }\end{array}$ & df & $\begin{array}{r}\text { Mean } \\
\text { Square }\end{array}$ & $\mathrm{F}$ & Sig. \\
\hline \multirow{3}{*}{$\begin{array}{l}\text { Performance } \\
\text { Expectancy }\end{array}$} & Between Groups & 22.978 & 12 & 1.915 & 1.831 & .085 \\
\hline & Within Groups & 33.467 & 32 & 1.046 & & \\
\hline & Total & 56.444 & & 44 & & \\
\hline \multirow[t]{3}{*}{ Effort Expectancy } & Between Groups & 15.363 & 12 & 1.280 & .997 & .473 \\
\hline & Within Groups & 41.081 & 32 & 1.284 & & \\
\hline & Total & 56.444 & & 44 & & \\
\hline \multirow[t]{3}{*}{ Social Influence } & Between Groups & 15.837 & 14 & 1.131 & .836 & .628 \\
\hline & Within Groups & 40.607 & 30 & 1.354 & & \\
\hline & Total & 56.444 & & 44 & & \\
\hline \multirow[t]{3}{*}{ Facilitating Conditions } & Between Groups & 15.661 & 13 & 1.205 & .916 & .548 \\
\hline & Within Groups & 40.783 & 31 & 1.316 & & \\
\hline & Total & 56.444 & & 44 & & \\
\hline \multirow{3}{*}{$\begin{array}{l}\text { Attitudes towards Use } \\
\text { of Technology }\end{array}$} & Between Groups & 11.194 & 12 & .933 & .660 & .775 \\
\hline & Within Groups & 45.250 & 32 & 1.414 & & \\
\hline & Total & 56.444 & & 44 & & \\
\hline \multirow[t]{3}{*}{ Usage Intention } & Between Groups & 6.786 & 8 & .848 & .615 & .759 \\
\hline & Within Groups & 49.658 & 36 & 1.379 & & \\
\hline & Total & 56.444 & & 44 & & \\
\hline \multirow[t]{3}{*}{ Anxiety } & Between Groups & 25.287 & 15 & 1.686 & 1.569 & .145 \\
\hline & Within Groups & 31.157 & 29 & 1.074 & & \\
\hline & Total & 56.444 & & 44 & & \\
\hline
\end{tabular}

Table 5 indicates that $\mathrm{F}$ value is not significant at 0.05 level of significance. So, it is concluded that there is no significant difference in the behavioural intentions of respondents from different programs of studies on all its factors for using mobile learning. 
International Journal of Distance Education and E- Learning (IJDEEL) Volume VI- Issue I (December 2020)

Table 6. Demographic Features of the Respondents $(\mathrm{N}=45)$

$\begin{array}{rrrrr} & \text { Frequency } & \text { Percent } & \text { Valid } & \text { Cumulative } \\ & & & \text { Percent } & \text { Percent } \\ & & & & \\ \text { male } & 9 & 20.0 & 20.0 & 20.0 \\ \text { female } & 36 & 80.0 & 80.0 & 100.0 \\ \text { Age } & & & & \\ & & & & \\ \text { below } 20 \text { years } & 17 & 37.8 & 37.8 & 37.8 \\ 20-25 \text { years } & 10 & 22.2 & 22.2 & 60.0 \\ 25-30 \text { years } & 8 & 17.8 & 17.8 & 77.8 \\ 30-35 \text { years } & 2 & 4.4 & 4.4 & 82.2 \\ 35-40 \text { years } & 4 & 8.9 & 8.9 & 91.1 \\ \text { above } 40 \text { years } & 4 & 8.9 & 8.9 & 100.0\end{array}$

Program of studies

$\begin{array}{rrrrr}\text { PhD } & 7 & 15.6 & 15.6 & 15.6 \\ \text { MPhil } & 10 & 22.2 & 22.2 & 37.8 \\ \text { masters } & 9 & 20.0 & 20.0 & 57.8 \\ \text { bachelors } & 19 & 42.2 & 42.2 & 100.0\end{array}$

Device type owned

\begin{tabular}{rrrrr} 
call \& text & 19 & 42.2 & 42.2 & 42.2 \\
smart phone & 25 & 55.6 & 55.6 & 97.8 \\
tablet & 1 & 2.2 & 2.2 & 100.0 \\
\hline
\end{tabular}


Table 6 shows the demographic characteristics of the respondents. It was found that majority of the respondents fall between two age groups which are below 20 years and between 20-25 years making a cumulative percentage of $60.00 \% .80 \%$ of respondents were female. $42.2 \%$ of the respondents belonged to bachelor programs of studies. It is revealed that majority of the respondents $(55.6 \%)$ possess a smart-phone.

Table7. Specific Features of the Respondents Regarding Availability and Use of Mobile Devices $(N=45)$

\begin{tabular}{|c|c|c|c|c|}
\hline & Frequency & Percent & $\begin{array}{c}\text { Valid } \\
\text { Percent }\end{array}$ & $\begin{array}{c}\text { Cumulative } \\
\text { Percent }\end{array}$ \\
\hline \multicolumn{5}{|l|}{ You use internet from your device } \\
\hline Daily & 33 & 73.3 & 73.3 & 73.3 \\
\hline Weekly & 6 & 13.3 & 13.3 & 86.7 \\
\hline Monthly & 5 & 11.1 & 11.1 & 97.8 \\
\hline Others & 1 & 2.2 & 2.2 & 100.0 \\
\hline \multirow{2}{*}{\multicolumn{5}{|c|}{$\begin{array}{l}\text { Do you have an } \\
\text { learning? }\end{array}$}} \\
\hline & & & & \\
\hline Yes & 42 & 93.3 & 93.3 & 93.3 \\
\hline No & 3 & 6.7 & 6.7 & 100.0 \\
\hline
\end{tabular}

Do you have access to internet $3 \mathrm{G} / 4 \mathrm{G}$ mobile networks?

$\begin{array}{lrrrr}\text { Yes } & 38 & 84.4 & 84.4 & 84.4 \\ \text { No } & 7 & 15.6 & 15.6 & 100.0\end{array}$

Did you ever use any educational application on your mobile device?

$\begin{array}{lllll}\text { Yes } & 35 & 77.8 & 77.8 & 77.8\end{array}$


International Journal of Distance Education and E- Learning (IJDEEL) Volume VI- Issue I (December 2020)

$\begin{array}{lllll}\text { No } & 10 & 22.2 & 22.2 & 100.0\end{array}$

Do you have access to educational

contents using $3 \mathrm{G} / 4 \mathrm{G}$ mobile

networks?

$\begin{array}{lllll}\text { Yes } & 34 & 75.6 & 75.6 & 75.6 \\ \text { No } & 11 & 24.4 & 24.4 & 100.0\end{array}$

Give your opinion about mobile learning

$\begin{array}{rrrrr}\text { good idea } & 40 & 88.9 & 88.9 & 88.9 \\ \text { good idea not to use } & 2 & 4.4 & 4.4 & 93.3 \\ \text { no good idea } & 3 & 6.7 & 6.7 & 100.0\end{array}$

Table 7 shows specific characteristics of the respondents related to use of mobile learning. Most of the respondents (73.3\%) use internet from their devices on a daily basis. $93.3 \%$ of the respondents have an idea of what mobile learning is? A large majority among the respondents $(84.4 \%$ ) has access to $3 \mathrm{G} / 4 \mathrm{G}$ networking from their devices. $77.8 \%$ of the respondents have used educational applications on their mobile devices. $75.6 \%$ among the respondents have access to educational contents using 3G/4G mobile networks. Majority of the respondents (88.9\%) consider mobile learning as a good idea.

\section{Findings}

The present study was designed to investigate factors affecting behavioural intentions to use mobile learning at higher education. The seven factors (performance expectancy, effort expectancy, social influence, facilitating conditions, attitudes towards the use of technology, usage intentions and anxiety)affecting behavioural intentions of respondents to use mobile learning were significantly correlated $(p<.01)$ in positive direction except for anxiety which was positively but not significantly correlated. Mean values of respondents' scores on the variables of behavioural intentions indicated that students often agreed on factors of behavioural intentions to use mobile learning except on the factor anxiety for which they sometimes agreed. The t-value for factors 
affecting behavioural intentions to use mobile learning indicated that there was no significant difference $(p>.05)$ between behavioural intentions of male and female respondents for using mobile learning. There was no significant difference $(p>.05)$ in behavioural intentions of respondents from different age groups for using mobile learning. There was no significant difference $(p>.05)$ in behavioural intentions of respondents from different programs (bachelor, Masters, M. Phil and $\mathrm{PhD}$ ) for using mobile learning. The demographic analysis showed that the respondent group included $60 \%$ of students of the age of 25 years or less. Majority of students (55.6\%) were using smart-phones. They (73.3\%) reported daily use of internet from their mobile devices. A majority (93.3\%) had an idea of what mobile learning is. They (84.4\%) had access to $3 \mathrm{G} / 4 \mathrm{G}$ internet networks from their mobile devices. Most of them (77.8\%) had used educational applications from mobile devices. Majority of the respondents $(75.6 \%)$ could reach educational contents by using their mobile devices. A greater number of respondents (88.9\%) had considered mobile learning a good idea.

\subsection{Discussion}

Liu, Han and $\mathrm{Li}$ (2010) has established that using technologies with reluctant users brings no benefits. The current investigation found that the students are using smart-phones, they have access to 3G/4G services of mobile internet and they have access to educational content through mobile phones. This proves the readiness of students for integration of mobile learning with conventional learning approaches. Furthermore, it was found that the factors of behavioural intentions in the use of mobile learning are positively related with behavioural intention to use mobile learning which confirmed the findings reported by Hassan et al., (2015). The current findings showed that difference in gender and age do not determine the behavioural intentions in the use of mobile learning. Male and female students from different age groups and different programs of studies showed no significant difference in their behavioural intentions in using mobile learning. Hence, gender, age and program of studies are not moderating the behavioural intentions in using mobile learning at higher education level. These findings are not consistent with findings reported by previous studies (Hassan et al., 2015; Sundar, 2015).

\subsection{Conclusions and Recommendations}

The present study concluded that our youth is ready to accept mobile learning at higher education level. At higher education level, mobile learning may become accessible source among 
students to learn effectively at a rapid pace as the majority of students are using smart-phones with 3G/4G internet technology. In Pakistan, the structural and organizational use of mobile learning technology is still in its infancy even at higher education level. Development of new models, methods, and systems in order to successfully integrate mobile learning in the current system of education is needed. In Pakistan, distance learning educational institutions like Allama Iqbal Open University, International Islamic University, Islamabad and Virtual University are the pioneers in applying modern electronic devices in their system for learning purpose. Due to the popularity of mobile phones, iPods and laptops among the student community, learning through electronic devices may become a common trend. This trend may be channelized in a positive direction by higher education authorities to benefit students. The current study concluded that students at higher education level have behavioural intentions to use mobile learning. For proper implementation of mobile learning in higher educational institutions in Pakistan, policies and planning framework is necessary. Special software and mobile material are required to be developed. Training of teachers and students is also necessary for the proper use of these devices. Besides pedagogical and technological knowledge, an updated curriculum is required that can be taught through mobile learning. Teachers may make learning interesting by using mobile devices regarding students' positive behavioural intentions. and can overcome the anxiety linked with the use of mobile learning. Efforts may be boosted for the development of software to incorporate mobile learning at higher education level. Short term courses may be arranged for the training of teachers and students to use mobile applications effectively for educational purposes. For further research, it is recommended that the behavioural intentions of university teachers to use mobile learning may also be investigated. Effective modes and applications in mobile learning at different educational levels may be investigated through further research.

\section{References}

Ajzen, I. \& Fishbein, M. (1980). Understanding Attitudes and Predicting Social Behavior Englewood Cliffs, NJ: Prentice-Hall, Inc.

Annual Report. (2017).Pakistan Telecommunication Authority Headquarters, F-5/1, Islamabad, Pakistan.ISBN: 978-969-8667-58-0 https://www.pta.gov.pkretrieved at 6:45 on August 19, 2018.

Attewell, J. \&Savill-Smith, C. (2005). Mobile Learning Anytime Everywhere, London: Learning and Skills Development Agency. 
Banks, K. (2008). Mobile Learning in Developing Countries: Present Realities and Future Possibilities. In S. Hirtz, \& D. M. Harper (Eds.), Education for a Digital World: Advice, Guidelines, and Effective Practice from Around the Globe (pp. 51-56), Vancouver, Canada: Commonwealth of Learning.

Barker, A., Krull, G. \& Mallinson, B. (2005). A Proposed Theoretical Model for M-Learning Adoption in Developing Countries .Proceedings of the 4th World Conference on mLearning, Cape Town, South Africa, 2005.

Davis. F. D. (1989). Perceived Usefulness, Perceived Ease of Use, and User Acceptance of Information Technology. MIS Quarterly, vol. 13, no. 3, pp. 319-340, 1989.

El-Hussein, M. O. M., \& Cronje, J. C. (2010). Defining Mobile Learning in the Higher Education Landscape. Educational Technology \& Society, 13 (3), 12-21.

Hassan, W. U., Nawaz, M. T., Syed, T. H., Arfeen, M. I., Naseem, A., \& Noor, S. (2015). Investigating Students' Behavioral Intention Towards Adoption of Mobile Learning in Higher Education Institutions of Pakistan. Technical Journal, University of Engineering and Technology (UET) Taxila, Pakistan.20(iii), 34-47.

Moon., V. Jones \& G. Cranitch. (2002). Innovations in e-Learning with Wireless Technology and Personal Digital Assistant Gold Coast Campus: Griffith University, Australia.

Liu, Y., Han, S., \& Li, H. (2010). Understanding the factors driving m-learning adoption: a literature review. Campus-Wide Information Systems.vol. 27, no. 4, pp. 210-226

Mcconatha, D., Praul, M., \& Lynch, M. J. (2008). Mobile Learning in Higher Education: an empirical assessment of a new educational tool. The Turkish Online Journal of Educational Technology, 7(3), 15-21.

Meisenberger, M., Nischelwitzer, A. (2004). The Mobile Learning Engine (MLE) a mobile computer-aided, multimedia-based learning application. http://www.mapec.at/docs/ MApEC_Proceedings.pdf

Ooms, A., Linsey, T., \& Webb, M.(2008). The in-classroom use of mobile technologies to support diagnostic and formative assessment and feedback. Paper presented at the 7th London International Scholarship of Teaching and Learning Conference, London, U.K. 2008 Kingston University.

Prensky, M., (2001). Digital native digital immigrants. The Horizone Report. MCB University Press, 9:5.

Sundari, T. T. (2015). Effects of mobile phone use on academic performance of college going young adults in India. International Journal of Applied Research, 1(19), 898-905. Retrieved from www.allresearchjournal.com

Ting, Y. R. (2005). Mobile Learning: Current Trend and Future Challenges. Proceedings of the Fifth International Conference on Advanced Learning Technologies, Los Alamitos, CA: IEEE Computer Society Press.

Venkatesh, V., Morris, M. G., Davis, G. B. \& Davis, F. D. (2003). User Acceptance of Information Technology: Toward a Unified View. MIS Quarterly, 27(3), 425-478. http://doi.org/10.1017/CBO9781107415324.004 
International Journal of Distance Education and E- Learning (IJDEEL) Volume VI- Issue I (December 2020)

Warshaw, P.R. \& Davis, F.D. (1985). Disentangling behavioural intention and behavioural expectation. Journal of Experimental Social Psychology, 21, 213-228 